\title{
Human-Capital based Governance Structure, Success Factors and Barriers to Effective Governance: Co-operatives in Malaysia
}

\author{
Rohana Othman $\mathrm{a}^{*}$, Huang Ching Choo ${ }^{\mathrm{b}}$, Suhana Zazale ${ }^{\mathrm{b}}$, Nooraslinda Abdul Aris ${ }^{\mathrm{b}}$ \\ aAccounting Research Institute, Universiti Teknologi MARA, Shah Alam 40450, Malaysia \\ ${ }^{b}$ Faculty of Accountancy, Universiti Teknologi MARA, Shah Alam 40450, Malaysia
}

\begin{abstract}
Co-operatives comprise the crucial third engine of growth for the Malaysian economy after the public and private sectors. This study investigates the human capital based governance structure, success factors and barriers to effective governance of co-operatives in Malaysia. Questionnaires were distributed to the top 100 co-operatives listed in the Malaysian Co-operative Societies Commission website. Analysis of the responses to the questionnaires showed that human capital based co-operatives governance comprise members' participation, independence of the board, depth of expertise and competencies of directors and other characteristics of the board. This study also identified branding as the most important success factor ahead of competitiveness and proximity. Malaysia's economy is projected to continue relying significantly on the performance of co-operatives. Thus, it is incumbent for greater attention to be given towards an effective governance that results in successful co-operatives.
\end{abstract}

(C 2016. The Authors. Published for AMER ABRA by e-International Publishing House, Ltd., UK. Peer-review under responsibility of AMER (Association of Malaysian Environment-Behaviour Researchers), ABRA (Association of Behavioural Researchers on Asians) and cE-Bs (Centre for Environment-Behaviour Studies, Faculty of Architecture, Planning \& Surveying, Universiti Teknologi MARA, Malaysia.

Keywords: Governance; branding; proximity; competitiveness

\section{Introduction}

A report from the Co-operative Societies Commission of Malaysia targeted co-operatives as the third engine for national development after the public and private sectors in the 9th Malaysia Plan. It is expected to contribute to increasing the GDP of Malaysia from $5 \%$ in 2013 and to $10 \%$ by 2020 . The co-operative runs like other businesses, such that its success or failure depends on a variety of factors. It is important that co-operative be successful financially. Zaridis \& Mousiolis (2014) states that the success and failures of co-operatives primarily relate to the structures of the organization that arises from the ownership and control. They also stated that the application of the right principles in the co-operatives makes the co-operatives survive, remain competitive and be successful. Bidin (2007) stated that key indicators of the future performance of co-operatives in Malaysia

\footnotetext{
* Corresponding author. Tel.: +603-5544-4987; fax: +603-5544-4992

E-mail address: rohana799@salam.uitm.edu.my
}

(C) 2016. The Authors. Published for AMER ABRA by e-International Publishing House, Ltd., UK. Peer-review under responsibility of AMER (Association of Malaysian Environment-Behaviour Researchers), ABRA (Association of Behavioural Researchers on Asians) and cE-Bs (Centre for EnvironmentBehaviour Studies, Faculty of Architecture, Planning \& Surveying, Universiti Teknologi MARA, Malaysia.

DOl: http://dx.doi.org/10.21834/e-bpj.v1i1.238 
relate to co-operatives that adopt new structures and systems in facilitating the development of the co-operatives and their willingness to share the knowledge. As co-operatives play a significant role in the Malaysian economy, it is vital that they practice effective governance to enhance their performance. Huang (2010) found that effective governance improves the social and financial performance of the firms. In the context of cooperative organizations, Franken \& Cook (2013) highlighted that a comprehensive understanding of the implications of co-operative governance requires consideration of trade-offs between its financial performance and effectively serving other needs of patron-members.

Co-operatives in Malaysia were established with the Co-operative Societies Enactment 1922 with the early objectives being, the improvement of standards of living in the rural areas and eradicating poverty. In time, the Malaysian Co-operative Societies Commission reported the formulation of the National Co-operative Policy I (2002-2010) and National Co-operative Policy II (2011-2020) are to provide guidance for co-operatives to improve its shortcoming in performance, thereby helping contribute to the national economic growth. Malaysian co-operatives are still lagging compared to other countries like the United States, France, and Japan in terms of their contribution towards the development of the economy (International Cooperative Alliance, 2013). To fulfill its role as the third engine for national development, co-operatives need to be efficiently managed with good governance for financial performance. However the lack of research on the factors that contribute to high performance of cooperatives and what constitute good governance in co-operatives raises a need to explore the governance structure, success factors and barriers to effective governance of co-operatives in Malaysia. Thus, this study aims to examine the governance structure as well as determine the success factors and barriers to effective governance of Malaysian co-operatives.

\section{Literature Review}

It is important for co-operatives to be successful for them to achieve their objectives and fulfill their social obligations to their members. Barton (1989) stated that all successful businesses are user focused, and this is especially true in co-operatives purposed to meet the needs of the users. The primary purpose of a co-operative is to satisfy the social, economic and cultural needs of members (International Co-operative Alliance, 2013). Harun \& Mahmood (2012) reiterated the success of co-operatives is deemed to be important as it contributes to the socio- economic development of the nation and determines the future direction of the co-operatives movement in Malaysia. As co-operatives play a significant role in the development of Malaysian economy, it is vital that they have effective governance in place to enhance their performance. Effective governance help to enhance the financial performance and sustainability of the co-operatives (Rohana et al.; 2015). Huang (2010) emphasized that firms with effective governance can maintain the trust of the stakeholders, customers and society in ensuring mutually sustained development. Othman et al. (2012) found that the success of the co-operatives not only relied on the efficiency and effectiveness of the governance and management but also on members' participation, board independence, breadth of expertise and competencies of directors, other characteristics of the board such as board size.

A co-operative has a unique governance structure that reflects its ownership and control by its user members. The structure supports its orientation towards providing benefits to its members. Components of a cooperative governance structure encompass members' participation and independence of the board, breadth of expertise and competencies of the directors, and other characteristics such as board size, length of service and transparency and disclosure (Ernst \& Young, 2012). Aini et al. (2012) found that participation from members is vital to the development of co-operatives in Malaysia. Rajaratnam et al.; (2010) found that members' active participation in co-operatives is commonly evident in the form of attendance at the annual general meetings and their supports for products or services of the co-operatives. In supporting this, Sarif \& Ismail (2010) found that the members of co-operatives spent $57 \%$ of their time in attending meetings and participating in seminar discussions in cooperatives. In another study, Amini and Ramezani (2008) claimed members' active participation in the administration of cooperatives is an important factor that influences the success of co-operatives. Cornforth (2004) found that participatory democracy is closely related to the co-operative principles and the board can count on the members in their decisions, as long as the members are satisfied that they have a good chance in democratic control.

Bruynis' et al. (2001) study on critical success factors for emerging agricultural marketing co-operatives in fifty-two American co-operatives defined success as 'satisfactory completion of something or the attainment of a desired object or end'. This study examined three success factors, namely proximity, branding, and competitiveness and governance structure adapted from Ernst \& Young's proposed model of effective governance for greater insight into co-operative governance in practice. The first success factor to effective governance in a cooperative is proximity that broadly denotes closeness or involvement of the members. The second success factor is branding. Branding serves to reinforce image and reputation of the co-operative and its products or services. Finally, competitiveness represents a cooperative's ability to compete in the global market (Martin Lopez \& Ruiz 
Guerra, 2011). Conversely, barriers to the effectiveness of cooperative governance include weak oversights and control mechanisms, conflicts between the principles of profitability and social objectives of co-operatives and lack of management skills.

\section{Research Methodology}

As at June 2015, there are 11,871 cooperatives in Malaysia with a total membership of 7.4 million, total paid up capital of RM13.49 billion and total assets amounting to RM116.79 billion (MCSC, 2015). The sample of this study comprises the top 100 Malaysian co-operatives listed by the Malaysian Co-operative Societies Commission in 2015. In Malaysia, a cooperative is deemed successful when the organization has attained satisfactory performance in terms of financials (earnings, assets and equity), business, management and adequate compliance with the standards established by the Malaysian Co-operatives Societies Commission (MCSC). The MCSC adopts the same criteria as the International Co-operative Alliances in ranking its top 100 co-operatives. In summary, the evaluation was based on the non-financial factors made up of good governance, services to members, social and environmental responsibilities and meeting the objectives of co-operatives. The top 100 co-operatives were those achieving scores of at least $15 \%$. The main data for this study is primary data gathered using the questionnaire survey. The questionnaire survey data is related to the success factors of co-operatives, barriers to effective governance and the importance of the governance structure of co-operatives. These categories examined in the questionnaire were adapted from Ernst \& Young's proposed enlightened co-operatives model.

In a nutshell, the Ernst \& Young model for enlightened co-operative governance successfully balanced winning practices reminiscent of many enterprises, while fostering optimum member engagement in line with the organization's core values and mission. Enlightened cooperatives advocate their unique values and principles, implement a governance structure that prioritizes members' needs and commit to remain competitive in the marketplace. The adoption of a solid governance structure resonating the leading practices of corporations, guided by tools and tactics purposed and uniquely driving the co-operative environment enhances cooperatives' potential to develop and grow as a competitive business model that promotes values ensuring collective benefits to shareholders, entire communities, nations, and people. Such co-operatives inspire market confidence to take their place as solid and distinctive entities contributing towards competitive economies and cohesive communities.

Questionnaires were distributed to the top management and directors of the top 100 Malaysian co-operatives since they are more knowledgeable about their co-operatives, being in the leadership position. The influence of their decision making attributes over organizational performance should render their feedbacks and comments to be relevant to the study. A total of 81 questionnaires were received from 100 questionnaires distributed.

\section{Results and Discussions}

This study advances knowledge in the context of co-operative governance in Malaysia which is currently lacking. The adoption of Ernst \& Young's model of governance structure enables greater insight into the co-operative governance in practice. It also provides a comprehensive understanding of the factors that determine the success and barriers in achieving good governance of Malaysian co-operatives.

The reliability assessment of the data collected on the 47 items for success factors, barriers to effective governance and governance structure are, $0.916,0.762$ and 0.921 respectively. Table 1 illustrates the overall means and standard deviations of the governance structure of co-operatives. It also reveals the means and standard deviations for all three aspects of governance structure (member participation and independence of the board, breadth of expertise and director competencies and other characteristics of the board) with their respective rankings. 
Othman , R., et .al. / $6^{\text {th }}$ AicE-Bs2015Barcelona, Spain, 30 Aug.- 04 Sep. 2015 / E-BPJ, Maiden Issue, 1(1) June 2016 (pp.394-400)

Table 1. Means and Standard Deviations for Governance Structure of Co-operatives

\begin{tabular}{llll}
\hline Governance Structure of Co-operatives & Rank & Mean & Std. Deviation \\
\hline Breadth of expertise and director competencies & 1 & 4.24 & 0.640 \\
\hline Member participation and independence of the board & 2 & 4.21 & 0.767 \\
\hline Other characteristics of the board & 3 & 4.04 & 0.768 \\
\hline Overall & & 4.16 & 0.725 \\
\hline
\end{tabular}

According to Rajaratnam et al. (2010), to manage the daily operations of co-operatives efficiently, board members and staff are to be equipped with the right competencies. Amongst the three perspectives of governance structure examined in this study, the breadth of expertise and director competencies has the highest mean of 4.24. This implies that Malaysian co-operatives do regard breadth of expertise and director competencies to be more important than the other two perspectives of the governance structure. Malaysian co-operatives regard participation and independence of board to be relatively less important than breadth of expertise and director competencies. However, they are more important than the other characteristics of the governance structure of co-operatives. Member participation and independence of the board is ranked second with a mean score of 4.21. This is in line with Harun \& Mahmood (2012) who found that strong membership base is the foundation of co-operatives. Similarly, Aini et al. (2012), Othman et al. (2012) and Amini \& Ramezani (2008) also found participation from members to be vital for the development of co-operatives. The lowest mean of 4.04 goes to the 'other characteristics of the board'. In this study, the other characteristics of the board cover board size, length of service and transparency and disclosure which may play a less important role in the co-operative governance structure.

Table 2 presents the overall means and standard deviations of co-operative success factors. It also shows the means and standard deviations of the three aspects (proximity, branding and competitiveness) of success factors as well as their rankings.

Table 2. Means and Standard Deviations success factors to Effective Governance

\begin{tabular}{llll}
\hline Success Factors of Co-operatives & Rank & Mean & Std. Deviation \\
\hline Branding & 1 & 4.35 & 0.653 \\
\hline Competitiveness & 2 & 4.35 & 0.682 \\
\hline Proximity & 3 & 4.27 & 0.693 \\
\hline Overall & & 4.32 & 0.676 \\
\hline
\end{tabular}

Branding is ranked top in this study with a mean score of 4.35 . As one of the objectives of co-operatives is to fulfill its economic and social obligation (International Co-operative Alliance, 2013), co-operatives regard branding as an important factor for co-operative success. Respondents' perception regarding branding implies that Malaysian co-operatives too viewed branding including co-operative image and reputation as important for the success of co-operatives. This is consistent with the results from Bello (2005) who claimed that the role of co-operatives is to deliver and offer better products and services for customers. The second most highly ranked factor is competitiveness, with the mean and standard deviation, 4.35 and 0.682 respectively. It is vital for co-operatives to attain competitive advantage to achieve sustainability. This ranking implies that Malaysian co-operatives do regard competitiveness to be important. According to Martin Lopez \& Ruiz Guerra (2011), to succeed, co-operatives must know how to deal successfully in a market that is highly competitive. Proximity is ranked third (last) in Table 2 but its mean score is close to 'important'. The mean and standard deviation values for proximity are 4.27 and 0.693 respectively. The result indicates that the closeness between the members and directors and their involvement play a less important role in the success of co-operatives as compared to competitiveness and branding.

Further, this study also seeks the opinion of the respondents on the barriers to effective governance in Malaysian cooperatives. The overall means and standard deviations of barriers to effective governance are shown in Table 3. The table also reveals the means and standard deviations for all eight barriers as well as their rankings. All the eight barriers have mean scores slightly greater than four. 'Weak oversight and control mechanisms' and 'lack of knowledge and awareness that co-operative are as important as other business' are the top two barriers to effective governance with the same mean score of 4.05 . Barriers 
ranked third to seventh are with the same mean score of 4.04 . These barriers are 'conflicts between the principles of profitability and social objectives', 'confusion about the role and mission of the co-operative', 'lack of clarity around the purpose of governance and board's role', 'risk of entrenching power among a selected group', and 'understanding that co-operatives are similar to private sector enterprises in term of profitability'. 'Lack of clear rules on how to adapt to changes in the market' is ranked last with a mean score of 4.01. The respondents do not regard a lack of clear rules on how to adapt to changes in the market as a barrier to effective governance as compared to other barriers.

Table 3. Mean and Standard Deviation of Barriers to effective Governance

\begin{tabular}{llll}
\hline Barriers to Effective Governance & Rank & Mean & $\begin{array}{l}\text { Std. } \\
\text { Deviation }\end{array}$ \\
\hline Weak oversight and control mechanisms & 1 & 4.05 & 0.522 \\
\hline $\begin{array}{l}\text { Lack of knowledge and awareness that cooperative are } \\
\text { as important as other business }\end{array}$ & 2 & 4.05 & 0.705 \\
\hline $\begin{array}{l}\text { Conflicts between the principles of profitability and social } \\
\text { objectives }\end{array}$ & 3 & 4.04 & 0.486 \\
\hline Confusion about the role and mission of the cooperative & 4 & 4.04 & 0.511 \\
\hline $\begin{array}{l}\text { Lack of clarity around the purpose of governance and } \\
\text { board's role }\end{array}$ & 5 & 4.04 & 0.535 \\
\hline Risk of entrenching power among a selected group & 6 & 4.04 & 0.558 \\
\hline $\begin{array}{l}\text { Understanding that cooperative are similar to private } \\
\text { sector enterprises in term of profitability }\end{array}$ & 7 & 4.04 & 0.558 \\
\hline $\begin{array}{l}\text { Lack of clear rules on how to adapt to changes in the } \\
\text { market }\end{array}$ & 8 & 4.01 & 0.512 \\
\hline Overall & & 4.04 & 0.548 \\
\hline
\end{tabular}

\section{Conclusions}

This study sought the opinions of respondents comprising of the top management of the co-operatives on the success factors of their co-operatives, the governance structure and barriers to effective governance of co-operatives. This study adapted the Ernst \& Young's proposed model of effective governance for greater insight into the cooperative governance in practice.

The governance structure of co-operatives of this study covers members' participation and independence of the board, the breadth of expertise and competencies of directors and other characteristics of the board. The breadth of expertise and competencies of directors were found to be more important as compared to the other two perspectives of the governance structure. The result could be in managing the operation of the co-operatives, the board, and the management are to be equipped with the right skill, training, and expertise. This study has found the leader's vision to be important for the effective governance structure of co-operatives in addition to strong leadership. A clear definition and segregation of the roles and responsibilities of CEO and board is regarded as important to the effective governance structure too.

Out of the three categories (branding, competitiveness, and proximity) of success factors examined, 'branding' was found to be the most important success factors for co-operatives as compared to competitiveness and proximity. The average mean score for branding was greater than four with $40 \%$ of respondents having regarded branding as a very important factor for the success of co-operatives in Malaysia. The social impact of products and services offered by co-operatives was one of the most important factors for the success of Malaysian co-operatives. Competitiveness was ranked as the second success factor. Respondents have regarded strong membership commitment and support and strong group cohesiveness to be more important than innovativeness and technological improvement of products and services. The last success factor was proximity. Though it was ranked last, the mean of 4.27 indicates that the closeness of the co-operatives with members and their involvement in the co-operatives are also an important success factor for Malaysian co-operatives. Like most of the co-operatives in the world, Malaysian co-operatives have found it vital for members to attend an annual general meeting as this is a good indication of members' involvement and contribute to the success of co-operatives. The respondents of this study did not think that members 
should actively take part in the administration of co-operatives for the success of the co-operatives unlike past studies that highlighted the need for nominating members for administrative post for co-operatives to promote the success of co-operatives. The respondents were also asked to identify the barriers faced by their co-operatives in building effective governance. The top two barriers identified in this study are weak oversight and control mechanism and lack of knowledge and awareness of effective governance.

In summary, the results of this study provide insight into the importance of governance structure of Malaysian co-operatives. To promote the growth of Malaysian co-operatives, it is insufficient just to focus on financial performance. This study provided a more comprehensive understanding of the governance structure and identified success factors and the barriers to effective governance. This helps to better regulate the co-operatives and enhance the growth of the national economy. As a closing notion, co-operatives, having mutualistic ownership structure that supports social components for socio-economic justice and equitable distribution and, as democratic organizations, offer ideal fertile grounds for further studies to explore juxtaposing Islamic governance tenets along the Maqasid Al-Syariah. This is also in keeping with Islamic precepts about inclusion and greater sharing of exposure to upside and downside risks reminiscent of the markets penetrated by co-operatives. Cooperatives may henceforth stand to benefit from Islamic governance to be more resilient and sustainable in the long term. This scenario presents potential for future studies. Future research can also extend to include non-top 100 co-operatives to have a better representation of the co-operatives in Malaysia.

\section{Limitations of Study}

This study only focused on the top 100 co-operatives in Malaysia using a mail survey questionnaire. The study suffered a setback from low response rate. In future, studies can be conducted via interviews or using case studies to investigate governance structure, success factors and barriers to effective governance. Further analyses need to be conducted by using other variables such as board composition, shareholding, duality, etc.

\section{Acknowledgements}

The authors wish to thank the Ministry of Education, Malaysia for funding the research project through the Fundamental Research Grant Scheme (FRGS) and the Research Management Centre (RMC) Universiti Teknologi MARA (UiTM) for the administrative support.

\section{References}

Aini, Y. M., Hafizah, H. A. K., \& Zuraini, Y. (2012). Factors Affecting Cooperatives' Performance in Relation to Strategic Planning and Members' Participation. Procedia - Social and Behavioral Sciences, 65, 100-105.

Amini, A. M., \& Ramezani, M. (2008). Investigating the Success Factors of Poultry Growers' Cooperatives in Iran's Western Provinces. World Applied Sci. J, 5 , 81-87.

Barton, D.G. (1989). What is a Cooperative? In D. Cobia (Ed.), Co-operatives in agriculture. New Jersey, USA:Prentice-Hall, Inc. p.1-20.

Bello, D. A. (2005). The Role of Cooperative Societies in Economic Development. The Nigerian Journal of Administrative Studies, Vol. 2, No. 3, p. 1-12.

Bidin, Y. H. (2007). Positioning knowledge management as key success factor in the growth of Co-operatives in Malaysia. Asian Academy of Managememt Journal, Vol 12, No. 1, 69-82

Bruynis, C., Goldsmith, P., Hahn, D. E., \& Taylor, W. J. (2001). Key success factors for emerging agricultural marketing Co-operatives. Journal of Cooperatives, 16, 14-24.

Cornforth, C. (2004). The governance of Co-operatives and mutual associations: a paradox perspective. Annals of Public and Cooperative Economics, 75(1), 1132.

Ernst and Young. (2012). Enlightened co-operative governance - Balancing performance with broader principles in co-operatives and mutual. (www.ey.com/Publication/vwLUAssets/Enlightened_co-operative_governance)

Franken, J. R., \& Cook, M. L. (2013). Impact of Board Structure and Process on Cooperative Performance. In 2013 Annual Meeting, August 4-6, 2013, Washington, DC (No. 149420). Agricultural and Applied Economics Association.

Harun, M. Z. M. B., \& Mahmood, R. B. (2012). The Relationship between Group Cohesiveness and Performance: An Empirical Study of Co-operatives Movement in Malaysia. International Journal of Cooperative Studies, 1(1), 15-20.

Huang, C. J. (2010). Corporate governance, corporate social responsibility and corporate performance. Journal of Management \& Organization, 16(5), 641-655. 
Martin Lopez, V.M. and Ruiz Guerra, I. (2011). Strategic Management for the Internationalization of Cooperative Markets. Procedia - Social and Behavioral Sciences, 24, 769-780.

Österberg, P., \& Nilsson, J. (2009). Members' perception of their participation in the governance of Co-operatives: the key to trust and commitment in agricultural Co-operatives. Agribusiness, 25(2), 181-197.

Othman, A., Kari, F., Jani, R., \& Hamdan, R. (2012). Factors Influencing Cooperative Membership and Share Increment: An Application of the Logistic Regression Analysis in the Malaysian Co-operatives. World Review of Business research, 2(5), 24-35.

Rajaratnam, S. D., Noordin, N., Said, M. S. A., Juhan, R., Hanif, F. M. (2010). Success factors of co-operatives in Malaysia: An exploratory investigation. Malaysian Journal of Co-operative Studies, 6, 1-17.

Rohana Othman, Roshayani Arshad, Nooraslinda Abdul Aris and Siti Maznah Mohd Arif. (2015). Organizational Resources and Sustained Competitive Advantage of Cooperative Organizations in Malaysia. Procedia - Social and Behavioral Sciences, 170, 120-127.

Sarif, S.M., \& Ismail, Y. (2010). Managerial roles and the training of Malaysian Co-operatives' Managers. Malaysian Journal of Co-operative Studies, 6, 49-62. International Cooperative Alliance. (2013). The World Co-operative Monitor: Exploring the Co-operative Economy. http://ica.coop/sites/defaultfiles/media_items/wcm2013_web.pdf (Retrieved: 12 Nov. 2014)

Zaridis, A.D. and Mousiolis, D.T. (2014). Entrepreneurship and SME's Organizational Structure - Elements of a Successful Business. Procedia - Social and Behavioral Sciences, 148, 463-467. 